\title{
PELATIHAN PERHITUNGAN HARGA POKOK PRODUKSI DENGAN MENGGUNAKAN FULL COSTING SEBAGAI DASAR PENENTUAN HARGA JUAL PEMPEK PADA UMKM PEMPEK MASAYU 212
}

\author{
Wiralestari, Edy Firza, dan Fitrini Mansur \\ Dosen Fakultas Ekonomi dan Bisnis Universitas Jambi \\ Email: wiranabilla@gmail.com; edyfirza@gmail.com; fitrinimansur@yahoo.co.id
}

\begin{abstract}
ABSTRAK
Usaha mikro kecil dan menengah atau sering disebut dengan UMKM merupakan salah satu industri yang turut bersaing dalam memajukan perekonomian di Indonesia. Dalam pembangunan ekonomi di Indonesia UMKM selalu digambarkan sebagai sektor yang memiliki peranan penting karena sebagian besar penduduk Indonesia hidup dalam kegiatan usaha kecil baik di sektor tradisional maupun modern. Oleh karena itu pemerintah harus lebih memperhatikan perkembangan UMKM di Indonesia karena dengan adanya UMKM akan membantu pemerintah dalam mengurangi masalah ekonomi di Indonesia. Manajemen yang belum baik seperti pencatatan akuntansi yang belum diterapkan, perhitungan harga pokok produk yang tidak akurat, bahkan penentuan harga dan keuntungan menggunakan taksiran merupakan permasalahan yang dialami oleh UMKM. Untuk itu diperlukannya informasi keuangan yang baik akan memberikan informasi posisi keuangan yang memadai serta kinerja UMKM dapat terukur salah satunya dengan menentukan harga pokok produksi.
\end{abstract}

\section{Kata Kunci : Pempek, Full Costing, UMKM}

\section{PENDAHULUAN}

\section{Latar Belakang}

Usaha kecil dan menengah (UKM) di berbagai negara termasuk di Indonesia merupakan salah satu penggerak perekonomian rakyat yang tangguh. Hal ini karena kebanyakan para pengusaha kecil dan menengah berangkat dari industri keluarga atau rumahan. Dengan demikian konsumennya juga berasal dari kalangan menengah ke bawah. Selain itu, peranan UKM terutama sejak krisis moneter tahun 1998 dapat dipandang sebagai katup penyelamat dalam proses pemulihan ekonomi nasional, baik dalam mendorong laju pertumbuhan ekonomi maupun penyerapan tenaga kerja.

Selain kemampuan mengatasi masalah pengangguran, sektor UKM juga memberikan kontribusi yang cukup besar terhadap Produk Domestik Bruto (PDB) Indonesia, yakni mencapai sekitar 56,7\%. Meskipun berperan besar dalam mendorong pertumbuhan ekonomi, akses UKM terhadap pembiayaan masih minim. Potensi besar UKM selama ini tidak didorong oleh akses pembiayaan yang memadai. Alasannya pelaku bisnis ini dianggap tidak memenuhi kriteria kredit perbankan. Hanya sekitar 20\% UKM Indonesia yang memiliki akses pembiayaan, selebihnya banyak yang mengandalkan pinjaman individu, bahkan rentenir (Badan Pusat Statistik. 2010).

Keuntungan merupakan hal utama yang ingin diperoleh oleh perusahaan demikian halnya dengan UMKM. Keuntungan yang maksimal merupakan tujuan dari UMKM atau kegiatan usaha yang dilakukannya. Semakin berkembangnya perusahaan yang diiringi dengan semakin kompleknya persaingan di pasar maka perusahaan dituntut untuk lebih efisien dan efektif 
dalam melakukan kegiatan produksi agar produk yang dihasilkan memiliki kualitas yang bagus sehingga memiliki daya jual yang bagus di pasar, namun selain memiliki kualitas yang baik perusahaan juga dituntut untuk menjual produknya dengan harga yang wajar agar mampu bersaing di pasar (Rachmayanti, 2011).

Penentuan harga pokok produksi merupakan hal yang sangat penting mengingat manfaat informasi harga pokok produksi adalah menentukan harga jual produk serta penentuan harga pokok persediaan produk jadi dan produk dalam proses yang akan disajikan dalam neraca (Batubara, 2013). Oleh karena itu perhitungan harga pokok produksi harus dilakukan dengan cermat dan teliti.

Kegiatan produksi memerlukan pengorbanan sumber ekonomi berupa berbagai jenis biaya untuk menghasilkan produk yang akan dipasarkan. Biaya-biaya ini akan menjadi dasar dalam penentuan Harga Pokok Produksi (HPP). Elemen-elemen yang membentuk Harga Pokok Produksi (HPP) dapat dikelompokkan menjadi tiga golongan besar yakni bahan baku langsung, tenaga kerja langsung, dan biaya overhead pabrik. Ketiga biaya tersebut harus dicatat dan diklasifikasikan secara cermat sesuai dengan jenis dan sifat biaya tersebut. Hal ini dimaksudkan untuk mempermudah perusahaan mengetahui berapa besarnya biaya sebenarnya yang dikeluarkan perusahaan untuk menghasilkan suatu produk yang disebut harga pokok produksi. (Setiadi, 2014).

UMKM Pempek Masayu 212 saat ini menentukan harga dan tingkat keuntungan menggunakan taksiran berdasarkan pengalaman produksi dan penjualan selama ini. Manajemen dan kekayaan pemilik masih berada dalam satu pengelolaan dan belum dipisahkan. Pencatatan akuntansi yang dilakukan pun hanya sebatas mencatat penjualan harian sehingga informasi keuangan belum disajikan secara lengkap.

\section{Permasalahan}

Permasalahan yang menjadi prioritas untuk segara diatasi sesuai dengan kesepakatan dengan mitra UMKM Pempek Masayu 212 adalah dalam perhitungan harga pokok produksi. Perhitungan harga pokok produksi akan dimulai dari pengklasifikasian semua biaya-biaya yang dikeluarkan hingga produk siap untuk dijual.

\section{TARGET DAN LUARAN}

\section{Harga Pokok Produksi}

Harga pokok adalah sejumlah nilai aktiva, tetapi apabila selama tahun berjalan aktiva tersebut dimanfaatkan untuk membantu memperoleh penghasilan. Harga pokok produksi adalah seluruh biaya baik secara langsung maupun tidak langsung yang dikeluarkan untuk memproduksi barang atau jasa yang merupakan operasi utama perusahaan dalam suatu periode tertentu. Harga Pokok Produksi menurut Bastian dkk $(2010 ; 49)$ adalah "kumpulan biaya produksi yang terdiri dari bahan baku langsung, tenaga kerja langsung dan biaya overhead pabrik ditambah persediaan produk dalam proses awal dan dikurang persediaan produk dalam proses akhir.

Penentuan harga pokok produksi bertujuan untuk mengetahui berapa besarnya biaya yang dikorbankan dalam pengolahan bahan baku menjadi barang jadi yang siap untuk dipakai dan dijual. Penentuan harga pokok produksi sangat penting dalam suatu perusahaan, karena 
merupakan salah satu elemen yang dapat digunakan sebagai pedoman dan sumber informasi bagi pimpinan untuk mengambil keputusan dan menentukan besarnya laba.

Harga pokok produksi meliputi biaya bahan baku, biaya tenaga kerja langsung dan biaya overhead pabrik. Harga pokok produksi melekat pada barang yang kemudian menjadi persediaan yang siap dijual. Kebijakan penetapan harga suatu produk oleh manajemen idealnya memastikan pemulihan atas semua biaya dan mencapai laba yang diinginkan. Saat barang terjual, pokok tersebut ditandingkan dengan pendapatan penjualan yang kemudian pada akhir periode disajikan dalam laporan laba rugi untuk memperoleh laba kotor.

Komponen-komponen harga pokok produk terdiri dari biaya bahan baku, biaya tenaga kerja langsung dan biaya overhead pabrik baik yang bersifat tetap maupun variabel. Konsep harga pokok tersebut tidak selalu relevan dengan kebutuhan manajemen. Oleh karena itu timbul konsep lain yang tidak memperhitungkan semua biaya produksi sebagai komponen harga pokok produk. Metode perhitungan harga pokok produk yaitu full costing dan variabel costing. Perbedaan pokok di antara kedua metode tersebut adalah terletak pada perlakuan terhadap biaya produksi yang bersifat tetap.

\section{Tujuan Penentuan Harga Pokok Produksi}

Berdasarkan empat laporan keuangan tersebut, elemen laporan keuangan dapat dibagi menjadi 6 (enam), yaitu: Aset, Utang, Ekuitas, Pendapatan, Biaya, dan Pengembalian Ekuitas. Keenam elemen tersebut, dapat diartikan sebagai berikut:

1. Aset adalah jenis penggunaan dana yang merupakan sumber daya ekonomis yang dimiliki oleh perusahaan.

2. Utang adalah salah satu sumber pemerolehan dana dari pinjaman pihak lain (kreditor), transaksi pembelian kredit, atau penggunaan barang/jasa belum dibayar.

3. Ekuitas adalah sumber pemerolehan dana yang berasal dari setoran pemilik dan akumulasi laba/rugi yang dihasilkan oleh perusahaan yang tidak dibagikan (laba ditahan). Khusus bagi usaha kecil mikro menengah, terkadang dalam ekuitas juga ada sumber dana yang berasal dari pemerintah, seperti hibah atau sumbangan.

4. Pendapatan adalah sumber pemerolehan dana yang berasal dari aktivitas perusahaan, baik bersifat operasional maupun non-operasional.

5. Biaya adalah jenis penggunaan dana yang merupakan pembayaran (non utang) yang dilakukan oleh perusahaan kepada pihak lain.

6. Pengembalian Ekuitas adalah jenis penggunaan dana untuk kepentingan pemilik, baik berupa pengambilan untuk kepentingan pribadi (prive) atau pengembalian ekuitas kepada pemegang saham (dividen).

\section{Manfaat Harga Pokok Produksi}

Untuk mengetahui laba atau rugi secara periodik suatu perusahaan dihitung dengan mengurangkan pendapatan yang diperoleh dengan biaya - biaya yang dikeluarkan untuk memperoleh pendapatan tersebut. Adapun manfaat dari penentuan harga pokok produksi secara garis besar adalah sebagai berikut :

1. Menentukan Harga Jual Produk. Perusahaan yang berproduksi massa memproses produknya untuk memenuhi persediaan di gudang dengan demikian biaya produksi dihitung untuk jangka waktu tertentu untuk menghasilkan informasi biaya produksi 
per satuan produk. Penentuan harga jual produk, biaya produksi per unit merupakan salah satu data yang dipertimbangkan disamping data biaya lain serta data non biaya.

2. Memantau Realisasi Biaya Produksi. Manajemen memerlukan informasi biaya produksi yang sesungguhnya dikeluarkan dibandingkan dengan rencana produksi yang telah ditetapkan, oleh sebab itu akuntansi biaya digunakan dalam jangka waktu tertentu untuk memantau apakah produksi mengkonsumsi total biaya produksi sesuai dengan yang diperhitungkan sebelumnya.

3. Menghitung Laba Rugi Periodik. Untuk mengetahui apakah kegiatan produksi dan pemasaran perusahaan dalam periode tertentu mampu menghasilkan laba bruto. Manajemen memerlukan ketepatan penentuan laba periodik, sedangkan laba periodik yang tepat harus berdasarkan informasi biaya dan penentuan biaya yang tepat pula.

4. Menentukan Harga Pokok Persediaan Produk Jadi dan Produk Dalam Proses yang Disajikan dalam Neraca. .Saat manajemen dituntut untuk membuat pertanggungjawaban perperiode, manajemen harus menyajikan laporan keuangan berupa neraca dan laporan laba rugi yang menyajikan harga pokok persediaan produk jadi dan harga pokok yang pada tanggal neraca masih dalam proses. Berdasarkan catatan biaya produksi yang masih melekat pada produk jadi yang belum di jual pada tanggal neraca serta dapat diketahui biaya produksinya. Biaya yang melekat pada produk jadi pada tanggal neraca disajikan dalam harga pokok persediaan produk jadi. Biaya produksi yang melekat pada produk yang pada tanggal neraca masih dalam proses pengerjaan disajikan dalam neraca sebagai harga pokok persediaan produk dalam proses.

\section{Perhitungan Harga Pokok Produksi Full Costing}

Kalkulasi biaya penuh (Full Costing) merupakan metode penentuan harga pokok produksi yang memperhitungakan semua unsur biaya produksi ke dalam harga pokok produksi, yang terdiri dari biaya bahan baku, biaya tenaga kerja dan biaya overhead pabrik baik yang berperilaku variabel maupun tetap (Mulyadi, 2009). Pada metode ini biaya overhead pabrik dibebankan kepada produk jadi atau ke harga pokok penjualan berdasarkan tarif yang ditentukan pada aktivitas normal atau aktivitas yang sesungguhnya terjadi.

Metode full costing memperhitungkan biaya tetap karena biaya ini dianggap melekat pada harga pokok persediaan baik barang jadi maupun persediaan barang dalam proses yang belum terjual dan dianggap harga pokok penjualan jika produk tersebut sudah habis dijual. Dengan demikian biaya produksi menurut metode full costing terdiri dari unsure-unsur biaya sebagai berikut :

\begin{tabular}{ll} 
Biaya bahan baku & $\mathrm{xx}$ \\
Biaya tenaga kerja langsung & $\mathrm{xx}$ \\
Biaya overhead pabrik variable & $\mathrm{xx}$ \\
Biaya overhead pabrik tetap & $\mathrm{xx}$ \\
\hline Harga Pokok Produksi & $\mathrm{xx}$
\end{tabular}




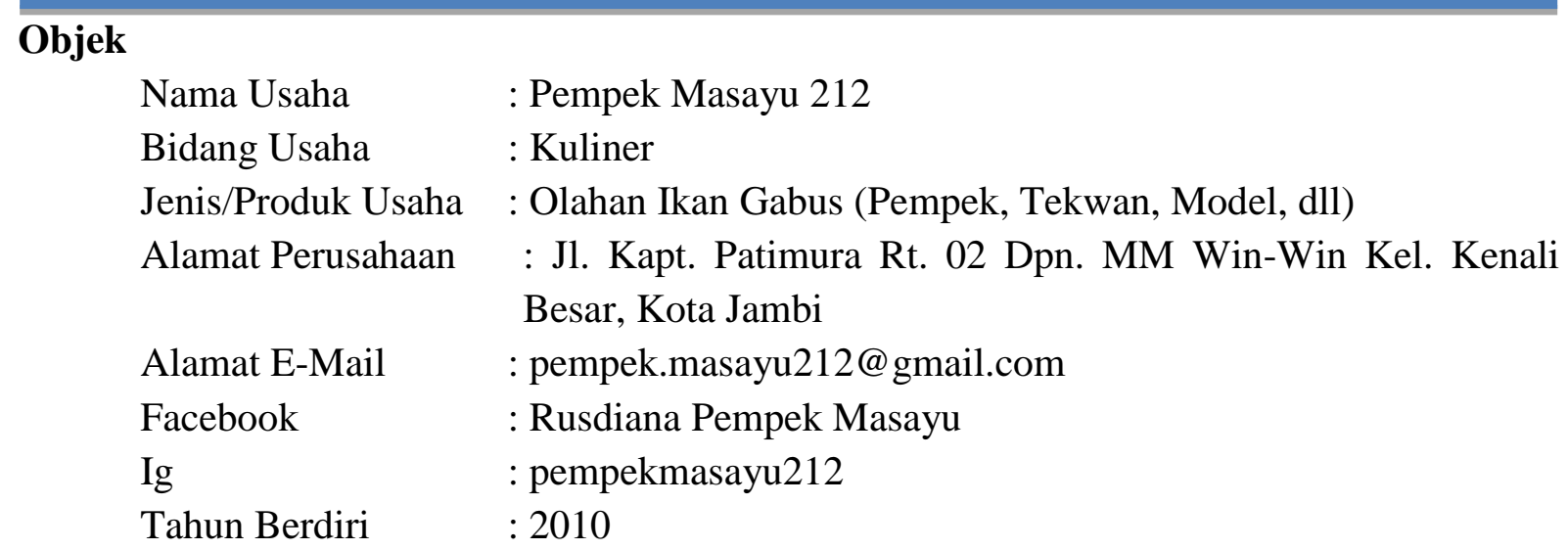

\section{METODE PELAKSANAAN}

Metode yang digunakan adalah sebagai berikut:

a. Langkah 1 (Metode Sosialisasi) :

Peserta diberikan sosialiasi tentang perhitungan harga pokok produksi.

b. Langkah 2 (Metode Tutorial):

Peserta pelatihan diberikan format laporan-laporan harga pokok produksi untuk melakukan pengisian laporan harga pokok produksi.

c. Langkah 3 (Metode Diskusi):

Peserta pelatihan diberikan kesempatan untuk mendiskusikan permasalahan yang berkaitan dengan keuangan desa yang selama ini dihadapi.

\section{HASIL YANG DICAPAI}

Perhitungan harga pokok produksi dengan metode perusahaan dan metode Full costing memiliki perbedaan. Pada perhitungan harga pokok produksi dengan metode Full costing harga pokok produksi yang dihasilkan lebih besar dibandingkan dengan perhitungan harga pokok produksi dengan metode perusahaan. Hal ini karena dengan menggunakan metode Full costing semua biaya dirinci secara jelas, baik itu biaya bahan baku, biaya tenaga kerja langsung dan biaya overhead pabrik. Sedangkan pada perhitungan harga pokok produksi dengan metode perusahaan harga pokok produksi yang dihasilkan lebih kecil karena perusahaan tidak memasukkan biaya overhead pabrik secara rinci ke dalam biaya produksinya. Untuk biaya listrik, biaya air, biaya penyusutan mesin, peralatan dan bangunan dan biaya pemeliharaan mesin tidak dibebankan oleh perusahaan oleh karena itu perhitungan biaya produksi dengan metode perusahaan lebih kecil dibanding dengan metode Full costing.

Kegiatan ini diawali dengan materi pertama yang diberikan adalah pengenalan atau pendahuluan mengenai akuntansi, pemateri memberikan penjelasan pentingnya akuntansi bagi UMKM. Mitra belum mengerti fungsi akuntansi, bahkan mitra menganggap bahwa akuntansi adalah bidang yang rumit, susah, merepotkan, menghabiskan waktu. Materi pertama ini diisi dengan penguatan pentingnya akuntansi bagi usaha kecil (UMKM). Pada sesi ini terjadi diskusi yang menarik antara mitra dengan pemateri mengenai konsep dasar penentuan harga pokok produksi. Mitra memiliki persepsi berbeda tentang bagaimana menentuan harga jual produknya berdasarkan perhitungan harga pokok produksi dalam hal ini berdasarkan metode 
Full Costing. Berdasarkan diskusi konsep entitas ini akhirnya diperoleh pemahaman mengenai penentuan dan perhitungan harga pokok produksi berdasarkan metode Full Costing.

Selanjutnya kegiatan dilanjutkan dengan materi kedua mengenai perhitungan harga pokok produksi dengan metode Full Costing. Pada sesi ini mitra diminta untuk mengidentifikasi apa saja biaya-biaya yang termasuk dalam perhitungan harga pokok produksi serta bagaimana peserta dalam hal ini mitra menentukan harga jual produknya berdasarkan perhitungan harga pokok produksi tersebut dengan metode Full Costing. Mitra diajarkan bagaimana menentukan harga jual suatu produk agar bisa bersaing dengan produk sejenis. Sehingga harga jualnya bisa kompetitif, artinya harga jual yang ditentukan tidak boleh terlalu mahal karena nantinya tidak akan dibeli oleh masyarakat dan juga harga jualnya tidak boleh terlalu murah sehingga pelaku UMKM akan mengalami kerugian akibat menjual terlalu murah. Penentuan perhitungan harga pokok produksi ini ternyata banyak peserta yang masih belum terlalu memahami apa-apa saja yang sebenarnya harus dilakukan. Sehingga peserta sangat antusias sekali saat sesi ini. Apalagi banyak peserta yang belum mengetahui apa itu metode Full Costing. Selanjutnya pelatihan di akhiri dengan praktik akuntansi perhitungan harga pokok produksi dan sekaligus penentuan harga jual produk bagi UMKM, dimana mitra diberikan soal latihan yang harus dikerjakan oleh masing-masing peserta sesuai dengan materi yang telah diberikan.

\section{KESIMPULAN DAN SARAN}

Kegiatan pelatihan perhitungan harga pokok produksi dengan metode Full Costing pada UMKM Pempek Masayu 212 berjalan dengan lancar. Setelah dilaksanakan kegiatan diketahui ternyata mitra hanya mengetahui perhitungan sederhana mengenai harga pokok produksi, Mitra selama ini menentukan harga jual dengan estimasi, saat ini mitra telah bisa menyesuaikan dengan perhitungan harga pokok produksi untuk penentuan harga jual. Mitra telah bisa menyusun harga pokok produksi dengan benar.

Mitra hendaknya selalu menghitung harga pokok produksi agar dapat menghitung laba yang lebih akurat. Perhitungan harga pokok produksi bisa juga diterapkan oleh mitra untuk produk lainnya yang dijual di UMKM Pempek Masayu 212.

\section{DAFTAR PUSTAKA}

Badan Pusat Statistik (BPS). 2010. Statistik Indonesia Tahun 2010.Badan PusatStatistik:Jakarta Pusat.

Bustami, B. dan Nurlela. 2010. Akuntansi Biaya Edisi Kedua. Mitra Wacana Media: Jakarta. Batubara, Helmina. 2013. Penentuan Harga Pokok Produksi Berdasarkan Metode Full Costing Pada pembuatan Etalase Kaca Dan Almunium di UD. Istana Almunium Manado. Jurnal Emba Vol.1 No.3 September 2013.

Darsono dan Ari Purwanti. 2010. Penganggaran Perusahaan Edisi Kedua. Mitra Wacana Media: Jakarta.

Hansen, Don R, dan Mowen, Maryanne M. 2006. Manajemen Biaya, Akuntansi dan Pengendalian, buku I edisi pertama. Salemba Empat: Jakarta

Hansen dan Mowen, 2012. "Akuntansi Manajerial”, buku I, edisi kedelapan, Salemba Empat, Jakarta 
Jurnal Karya Abdi Masyarakat

Volume 2 Nomor 1 Januari - Juni 2018

Mulyadi. 2009. Akuntansi Biaya, edisi kelima. UPP STIM YKPN: Yogyakarta

Rachmayanti Dewi Kasita. 2011. Analisis Perhitungan Harga Pokok Produksi Sepatu dengan Metode Full Costing (Studi Kasus UKM Galaksi Kampung Kabandungan Ciapus, Bogor). Institut Pertanian Bogor.

Setiadi Pradana. 2014. Perhitungan Harga Pokok Produksi Dalam Menentukan Harga Jual Pada CV. Minahasa Mantap Perkasa. Jurnal Berkala Ilmiah Efisiensi Volume 14, Nomor 2 Mei 2014.

Supriono, R.A. 2003. Akuntansi Biaya. BPFE Universitas Gajah Mada: Yogyakarta 